University of Nebraska - Lincoln

DigitalCommons@University of Nebraska - Lincoln

Publications from USDA-ARS / UNL Faculty

U.S. Department of Agriculture: Agricultural

Research Service, Lincoln, Nebraska

2004

Elemental Uptake in Relation to Root Characteristics of Tall

Fescue

Glenn E. Shewmaker

University of Idaho, gshew@uidaho.edu

Douglas A. Johnson

USDA-ARS Forage and Range Research Lab

Henry F. Mayland

USDA-ARS

Scott A. Martin

University of Georgia

Susie B. Hansen

USDA-ARS

Follow this and additional works at: https://digitalcommons.unl.edu/usdaarsfacpub

Part of the Agricultural Science Commons

Shewmaker, Glenn E.; Johnson, Douglas A.; Mayland, Henry F.; Martin, Scott A.; and Hansen, Susie B., "Elemental Uptake in Relation to Root Characteristics of Tall Fescue" (2004). Publications from USDA-ARS / UNL Faculty. 541.

https://digitalcommons.unl.edu/usdaarsfacpub/541

This Article is brought to you for free and open access by the U.S. Department of Agriculture: Agricultural Research Service, Lincoln, Nebraska at DigitalCommons@University of Nebraska - Lincoln. It has been accepted for inclusion in Publications from USDA-ARS / UNL Faculty by an authorized administrator of DigitalCommons@University of Nebraska - Lincoln. 


\title{
Elemental Uptake in Relation to Root Characteristics of Tall Fescue ${ }^{\#}$
}

\author{
Glenn E. Shewmaker, ${ }^{1, *}$ Douglas A. Johnson, ${ }^{2}$ \\ Henry F. Mayland, ${ }^{3}$ Scott A. Martin, ${ }^{4}$ and Susie B. Hansen ${ }^{3}$ \\ ${ }^{1}$ University of Idaho, Twin Falls Center, Twin Falls, Idaho, USA \\ ${ }^{2}$ USDA-ARS Forage and Range Research Lab, Utah State \\ University, Logan, Utah, USA \\ ${ }^{3}$ USDA-ARS, Northwest Irrigation and Soils Res. Lab, \\ Kimberly, Idaho, USA \\ ${ }^{4}$ Animal and Dairy Science Complex, University of Georgia, \\ Athens, Georgia, USA
}

\begin{abstract}
HiMag, an accession of tall fescue (Festuca arundinacea Schreb.), was selected for high magnesium $(\mathrm{Mg})$ concentration in leaves to reduce grass tetany risk to ruminants. However, the mechanism for enhanced $\mathrm{Mg}$ uptake in HiMag leaves has not been determined. The objective was to investigate if increased $\mathrm{Mg}$ uptake in HiMag could be explained by differences in elemental distribution among plant parts, root
\end{abstract}

\#University of Idaho Ag. Expt. Sta. No. 01709.

*Correspondence: Glenn E. Shewmaker, Ph.D., Extension Forage Specialist, University of Idaho, Twin Falls Center, P.O. Box 1827, Twin Falls, ID 833031827, USA; Fax: 208-736-0843; E-mail: gshew@uidaho.edu. 
characteristics, or organic acid concentrations compared to its parental cultivars, "Kentucky 31" (KY31) and "Missouri 96" (MO96). The study was conducted on a surface-irrigated calcareous Portneuf silt loam (coarse-silty, mixed, mesic, Durinodic Xeric Haplocalcid). Vegetation and soil cores of 7.6-cm diameter were sampled to a $45-\mathrm{cm}$ soil depth in $15-\mathrm{cm}$ increments. Mass and ash were determined for leaves, crowns, and roots. Leaf area, root length, root area, root length density, elemental concentration, and uptake [potassium $(\mathrm{K})$, calcium $(\mathrm{Ca}), \mathrm{Mg}$, sodium $(\mathrm{Na})$, and phosphorus $(\mathrm{P})$ ], and malate and citrate concentrations also were determined. Leaf $\mathrm{Mg}$ concentration was higher in HiMag than parental cultivars. HiMag generally did not differ in crown and root elemental concentrations from its parents. Risk of causing grass tetany, indicated by leaf $\mathrm{K} /(\mathrm{Ca}+\mathrm{Mg})$, was lower in HiMag than $\mathrm{KY} 31$ and MO96 in both $1994(P=0.03)$ and $1995(P=0.01)$. Root length, area, and mass were not related to cation concentrations in the three tall fescue accessions, suggesting that HiMag may have an active uptake or transport mechanism for $\mathrm{Mg}$.

Key Words: Herbage; Festuca arundinacea; HiMag; Root length; Root area; Magnesium; Calcium; Potassium; Phosphorus; Malate; Citrate.

\section{INTRODUCTION}

Cool-season grasses provide an important forage resource throughout temperate regions of the world. However, elemental imbalances in herbage may lead to hypomagnesemia (commonly known as grass tetany), a metabolic disorder in ruminant animals identified by low blood serum $\mathrm{Mg}$, which causes animal production and death losses. ${ }^{[1]}$ These losses are estimated at $\$ 400$ million annually in the United States, ${ }^{[2]}$ and $40 \%$ of these losses are believed to occur on the 12-14 Mha of tall fescue (Festuca arundinacea Schreb.). ${ }^{[3]}$ To help alleviate these losses, Sleper et al., ${ }^{[4]}$ and Mayland and Sleper ${ }^{[5]}$ selected a tall fescue accession, HiMag, for reduced $\mathrm{K} /(\mathrm{Ca}+\mathrm{Mg})$ and high $\mathrm{Mg}$ and $\mathrm{Ca}$ levels in herbage of the second generation from parental cultivars, "Kentucky 31" $(\mathrm{KY} 31)^{[6]}$ and "Missouri 96" (MO96). ${ }^{[7]}$ The ratio of $\mathrm{K} /(\mathrm{Ca}+\mathrm{Mg})$ is an index used to predict grass tetany incidence, that increases exponentially when $\mathrm{K} /(\mathrm{Ca}+\mathrm{Mg})$, calculated in moles of charge, exceeds $2.2 .{ }^{[8]}$

Despite the promise of forage cultivars with reduced tetany risk, little is known about the mechanisms for absorption and partitioning of $\mathrm{Mg}$, $\mathrm{Ca}$, and $\mathrm{K}$ in cool-season grasses. HiMag provided about $20 \%$ more leaf 
Mg than its parents, KY31 and MO96, on both acidic Typic Hapludults in Georgia ${ }^{[9]}$ and a calcareous Durinodic Xeric Haplocalcid soil in Idaho. ${ }^{[5]}$ The mechanism of increased Mg uptake in HiMag is not known. It was hypothesized that high leaf $\mathrm{Mg}$ concentrations were due to differences in root characteristics, ability to absorb greater amounts of $\mathrm{Mg}$ into the roots, or a difference in elemental transport. In addition, because organic acids exuded from roots may influence the rhizoshpere to affect ion solubility and uptake by plants, ${ }^{[10]}$ it was hypothesized that malate and citrate concentrations in HiMag may be higher than KY31 and MO96. The objective of this study was to determine if enhanced $\mathrm{Mg}$ uptake in HiMag is associated with differences in elemental distribution among plant parts, root characteristics, or root tissue malate and citrate concentrations.

\section{MATERIALS AND METHODS}

Three tall fescue accessions: HiMag, KY31, and MO96 were sown $\left(4.7 \mathrm{~kg}\right.$ seed ha $\left.{ }^{-1}\right)$ on 20 Sept. 1991 in six $7.6-\mathrm{m}$ long rows spaced at $0.56 \mathrm{~m}$ in a randomized complete block design.$^{[1]}$ Accessions were free of a fungal endophyte [(Neotyphodium coenophialum Morgan-Jones and Gams) Glen, Bacon and Hanlin comb. nov.] that reduces cattle performance. The soil was a surface-irrigated Portneuf silt loam (coarse-silty, mixed, mesic, Durinodic Xeric Haplocalcid) near Kimberly, ID, USA $\left(42^{\circ} 30^{\prime} \mathrm{N}\right.$ and $114^{\circ} 8^{\prime} \mathrm{W}$, elevation $1200 \mathrm{~m}$ ). This calcareous soil has an average $\mathrm{pH}$ of 7.7 which may allow soil $\mathrm{P}$ to be fixed as $\mathrm{Ca}_{3}\left(\mathrm{PO}_{4}\right)_{2}$. However, soil test $\mathrm{P}$ levels were adequate (Table 1). In October and again on 1 April of each year, plants were flail-mowed to a height of $8 \mathrm{~cm}$, fertilized with $56 \mathrm{~kg} \mathrm{~N} \mathrm{ha}^{-1}$ as broadcast urea or ammonium nitrate, and then irrigated using furrows spaced $1.1 \mathrm{~m}$ apart.

\section{Plant Sample Collection and Processing}

Concentrations of $\mathrm{Ca}, \mathrm{Mg}$, and $\mathrm{K}$ were evaluated in roots, crowns, and leaves of HiMag, MO96, and KY31 during 1994 and 1995. Malate and citrate concentrations in root tissue were analyzed in 1994 samples. Leaves within a 7.6-cm diameter ring centered on the row were clipped to a 7.6-cm stubble height from two rows at randomly selected points along the 6.7-m long row. Leaf fresh weight was recorded, and leaf area was determined on a 10-g (1994) or 5-g (1995) subsample. After clipping leaves, a $7.6-\mathrm{cm}$ diameter core was extracted from the soil on 20 April 


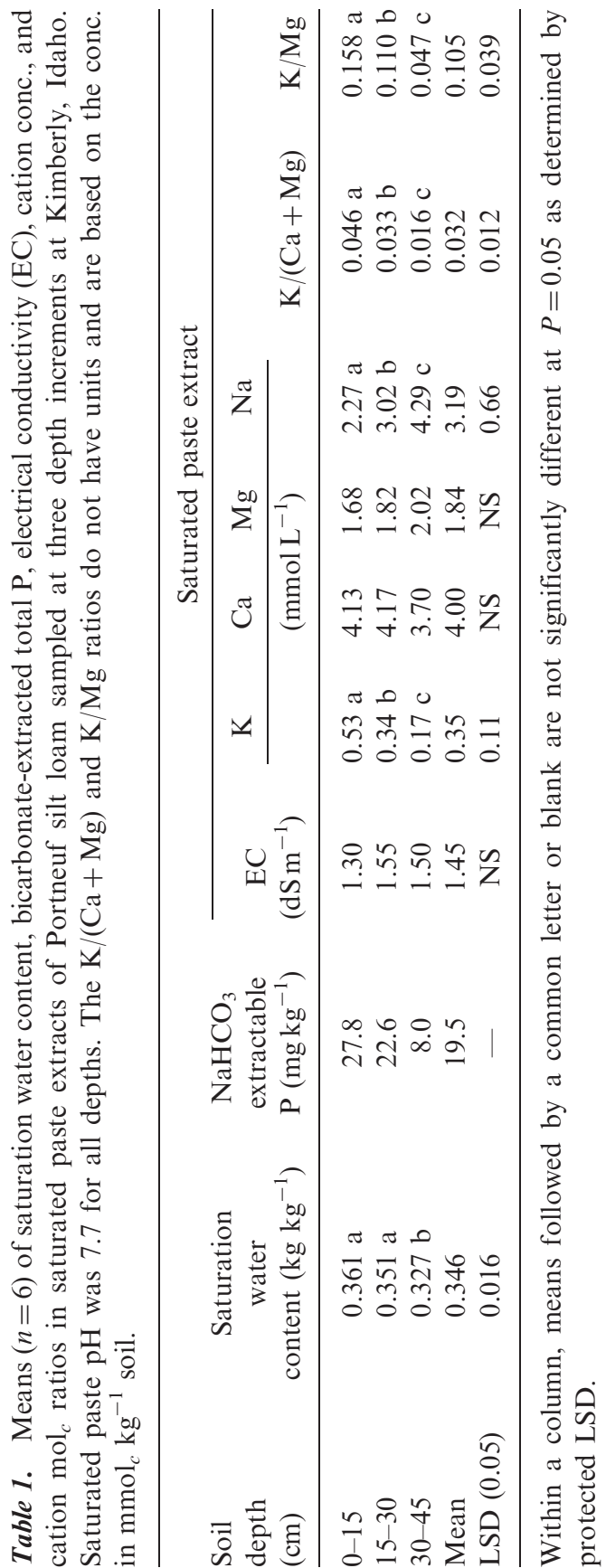


1994 and 24 April 1995. A second soil core was extracted $20 \mathrm{~cm}$ perpendicular to the row. Cores were sectioned into crown (row center only), 0-15 (R1), 15-30 (R2), and 30-45 cm (R3) depths. Crowns and soil cores were covered by plastic, stored at $3^{\circ} \mathrm{C}$, and washed within $3 \mathrm{~d}$. Core sections were placed on 1-mm nylon mesh screen, and soil was washed from the root sections. Cleaned roots and crowns were rinsed with distilled water, blotted, weighed, and placed into plastic bags. Root image analysis was performed on one half of the R1 section in 1994 and one quarter of the R1 section in 1995. One half of the R2 and R3 sections was image analyzed in both years after refrigeration at $3{ }^{\circ} \mathrm{C}$. Roots for chemical analyses, leaves, and crowns were frozen, freeze dried, weighed, and ground in a Wiley mill to pass a 1-mm stainless steel screen.

\section{Root Length and Area}

Roots used for length and area determination were soaked for $1 \mathrm{~h}$ in a $150 \mathrm{~mL}$ solution of $135 \mu \mathrm{g}$ methylene blue $\mathrm{L}^{-1}$ at $21^{\circ} \mathrm{C}$, rinsed with $100 \mathrm{~mL}$ deionized water, cut into $1-\mathrm{cm}$ lengths, and arranged to minimize intersections and overlapping in a glass tray with about 1-mm water depth. Root length and area were determined using an AgVision video camera and digitizing board. ${ }^{a}$ AgVision (Decagon Devices, P.O. Box 835, Pullman, WA) software uses a modification ${ }^{[12]}$ of the line-intercept procedure developed by Tennant. ${ }^{[13]}$ Root length density was calculated by dividing root length by core section volume. Root length ratio was calculated by dividing large root length by small root length. Root area ratio was calculated as the large root area divided by the small root area. Large and small root lengths were also expressed as $\mathrm{cm} \mathrm{g}^{-1}$ root dry matter (DM).

The methylene blue staining procedure allowed imaging of all but the finest roots (estimated as $<0.05 \mathrm{~mm}$ diameter). The precision of length and area determination was high with only a $3.8 \%$ error for known lengths and diameters of wire and black vinyl tubing repositioned with slight overlap 10 times. However, detection of fine roots depends on light intensity, camera height, and aperture setting. Thus, relative lengths and areas have high precision, but absolute values are less accurate.

${ }^{a}$ Mention of a trade does not imply an endorsement or recommendation by the University of Idaho or USDA over similar companies or products not mentioned. 


\section{Chemical Analyses}

A 0.5 -g subsample for each plant part was ashed in an oven at $482^{\circ} \mathrm{C}$ for $10 \mathrm{~h}$. Ash was dissolved with $10 \mathrm{~mL} 1 \mathrm{M} \mathrm{HNO}_{3}$, diluted to $50 \mathrm{~mL}$ with deionized distilled water, and filtered through Whatman No. 50 filter paper. An aliquot was diluted with $1 \mathrm{~g} \mathrm{La} \mathrm{L}^{-1}$ deionized distilled water and analyzed for $\mathrm{Mg}, \mathrm{Na}$, and $\mathrm{Ca}$ by atomic absorption spectroscopy and for $\mathrm{K}$ by flame emission (Perkin Elmer atomic absorption model 5000 , Norwalk, CT). The $\mathrm{LaCl}$ is used in the dilution to reduce chemical interference by $\mathrm{P}$ on $\mathrm{Ca}$ determination. ${ }^{[14]}$ Another aliquot was diluted with water, and $\mathrm{P}$ was determined colorimetrically using the vanadomolybdate procedure. ${ }^{[15]}$ Unstained roots in the R1 section of three replications in 1994 were analyzed for malate and citrate by high pressure liquid chromatography using an organic acid column. ${ }^{[16]}$

Twenty soil cores (2.5-cm diameter) corresponding to R1, R2, and R3 were composited by depth for each replication on 25 March 1994. Soil $\mathrm{pH}$ was determined on the saturated soil paste, and electrical conductivity (EC) was determined on the saturated soil paste extract. ${ }^{[17]}$ Calcium and $\mathrm{Mg}$ cations in the extract were analyzed by atomic absorption in a $10 \mathrm{~g} \mathrm{La} \mathrm{L}^{-1}$ matrix, and $\mathrm{Na}$ and $\mathrm{K}$ were analyzed by flame emission spectroscopy. ${ }^{[17]}$

\section{Statistical Analyses}

Each of the three accessions was replicated six times in a randomized complete block. Physical measurements and chemical data were analyzed with plant part as the sub-plot and year as the sub-sub-plot and analyzed as a split-plot in time model. ${ }^{[18]}$ Data were analyzed by least squares to fit general linear models (SAS Institute Inc., SAS Campus Drive, Cary, NC). Experimental units were accessions (main plots) obtained by reducing row data to plot means within replications and years. Plant samples were partitioned into roots (three soil depths), crowns, and leaves. Significance of accessions was tested by the replication $\times$ accession interaction, and significance of plant parts was tested by the replication $\times$ plant part interaction. Preplanned contrasts between HiMag vs. KY31 and MO96 were conducted. Physical and chemical variables were subjected to correlation analysis. Soil properties were subjected to protected LSD mean separation at three soil-depth increments. All variables were normally distributed. 


\section{RESULTS}

Saturated soil paste extracts contained $1.8 \mathrm{mmol} \mathrm{Mg}{ }^{2+} \mathrm{L}^{-1}$ and $4.0 \mathrm{mmol} \mathrm{Ca}^{2+} \mathrm{L}^{-1}$ and did not differ with depth (Table 1). The $\mathrm{K}$ concentration decreased with depth, while $\mathrm{Na}$ concentration increased with depth. Soil solution K concentration in the $30-45 \mathrm{~cm}$ depth was about $32 \%$ of the $0-15 \mathrm{~cm}$ depth. Thus, roots growing at the lower soil depth had considerably more favorable $\mathrm{K} /(\mathrm{Ca}+\mathrm{Mg})$ and $\mathrm{K} / \mathrm{Mg}$ ratios in the soil solution than at shallower depths. A lower $\mathrm{K} /(\mathrm{Ca}+\mathrm{Mg})$ ratio in soil solution should allow for a lower grass tetany risk in the plant tissue.

In the overall analysis of the data, plant parts differed significantly for ash, all elemental concentrations, and cation $\mathrm{mol}_{c}$ ratios. The year $\times$ part interaction was significant for ash, elemental concentrations (except for $\mathrm{Ca}$ and $\mathrm{P}$ ), and cation $\mathrm{mol}_{c}$ ratios. As a result, separate ANOVAs were conducted for each plant part in each year including leaves, crowns, and roots (R1, R2, and R3 depths in the center core and side core). For roots, accessions did not vary for any chemical or physical characteristic in the center or side cores, thus only center core data are presented. However, differences in both chemical and physical root characteristics were observed across root depths. Root depth and the year $x$ depth interaction were significant for length, area of large and small roots, and total root mass. The year $\times$ accession interaction was not significant for elemental concentrations, but was significant for all physical root characteristics except total root mass. The significant year $\times$ accession interaction may have been caused by a differential response of accessions to yearly differences in air and soil temperatures. Average maximum air temperature was 17.8 during 6-20 April 1994 compared to $12.8^{\circ} \mathrm{C}$ during 10-24 April 1995. Average maximum 10-cm soil temperature was $13.8^{\circ} \mathrm{C}$ during 6-20 April 1994 compared to $10.9^{\circ} \mathrm{C}$ during 10-24 April 1995.

\section{Leaves and Crowns}

HiMag contained more $\mathrm{Mg}(P=0.08)$, more $\mathrm{Ca}(P=0.08)$, and a lower $\mathrm{K} /(\mathrm{Ca}+\mathrm{Mg})(P=0.03)$ in leaves than the parental cultivars in 1994 (Table 2). In 1995 HiMag contained less $\mathrm{K}$, more $\mathrm{Mg}$ and $\mathrm{P}$, and lower $\mathrm{K} /(\mathrm{Ca}+\mathrm{Mg})$ and $\mathrm{K} / \mathrm{Mg}$ ratios than parental cultivars. Coefficients of variation $(\mathrm{CV})$ were low for leaf concentrations of $\mathrm{K}, \mathrm{Ca}$, and $\mathrm{Mg}$, ranging from 5 to $11 \%$ for both years. Leaf mass was about fourfold greater in 1994 than 1995. The lower leaf masses in 1995 were associated with physiologically younger leaves because the average minimum air 
Table 2. Mean $(n=6)$ mass, elemental concentration, and cation $\operatorname{mol}_{c}$ ratios for leaves; CV and contrast (HiMag vs. KY31 plus MO96) probabilities of three tall fescue accessions in a 7.6-cm diameter core for 1994 and 1995. Concentrations are expressed on a tissue dry matter basis.

\begin{tabular}{|c|c|c|c|c|c|c|c|c|}
\hline & \multirow[b]{3}{*}{ Mass (g) } & \multicolumn{5}{|c|}{ Concentration } & & \\
\hline & & $\mathrm{K}$ & $\mathrm{Ca}$ & $\mathrm{Mg}$ & $\mathrm{Na}$ & $\mathrm{P}$ & \multicolumn{2}{|l|}{ Ratio $^{\mathrm{a}}$} \\
\hline & & \multicolumn{5}{|c|}{$\left(\mathrm{g} \mathrm{kg}^{-1}\right)$} & $\mathrm{K} /(\mathrm{Ca}+\mathrm{Mg})$ & $\mathrm{K} / \mathrm{Mg}$ \\
\hline \multicolumn{9}{|l|}{1994} \\
\hline HiMag & 3.17 & 29.1 & 5.74 & 3.12 & 1.44 & 2.74 & 1.39 & 2.94 \\
\hline KY31 & 2.87 & 29.7 & 5.31 & 2.87 & 1.60 & 2.89 & 1.53 & 3.26 \\
\hline MO96 & 3.81 & 30.7 & 5.19 & 2.74 & 1.44 & 2.82 & 1.63 & 3.50 \\
\hline CV (\%) & 11 & 5 & 9 & 11 & 28 & 5 & 10 & 11 \\
\hline Contrast $^{\mathrm{b}}$ & NS & NS & 0.08 & 0.08 & NS & NS & 0.03 & 0.03 \\
\hline \multicolumn{9}{|l|}{1995} \\
\hline HiMag & 0.77 & 21.5 & 5.50 & 2.92 & 0.97 & 3.14 & 1.07 & 2.29 \\
\hline KY31 & 0.87 & 24.0 & 4.87 & 2.40 & 0.86 & 3.09 & 1.40 & 3.15 \\
\hline MO96 & 0.86 & 23.4 & 5.18 & 2.52 & 1.22 & 2.65 & 1.29 & 2.92 \\
\hline CV (\%) & 24 & 6 & 8 & 10 & 25 & 10 & 9 & 11 \\
\hline Contrast $^{\mathrm{b}}$ & NS & 0.01 & 0.04 & 0.01 & NS & 0.10 & 0.01 & 0.01 \\
\hline
\end{tabular}

${ }^{a}$ Ratios are unit-less but are calculated on a $\operatorname{mol}_{c}$ basis.

${ }^{\mathrm{b}}$ Indicates the $P$ level that means of HiMag vs. its parents, KY31 and MO96, are different by single df $t$ test, $\mathrm{NS}=$ not significant.

temperature in the $14 \mathrm{~d}$ prior to sampling was $2.2^{\circ} \mathrm{C}$ in 1994 compared to $-1.5^{\circ} \mathrm{C}$ in 1995 . Leaf area within the $7.6-\mathrm{cm}$ diameter core averaged 12.5 (1994) and $3.0 \mathrm{~cm}^{2}$ core $^{-1}$ (1995). Leaf ash averaged 119 (1994) and $103 \mathrm{~g} \mathrm{~kg}^{-1}$ dry matter (1995). Leaf $\mathrm{K}$ and $\mathrm{Mg}$ concentrations also were greater in 1994 than 1995 for all accessions. The $\mathrm{K} /(\mathrm{Ca}+\mathrm{Mg})$ and $\mathrm{K} / \mathrm{Mg}$ ratios were also higher in 1994 than 1995, but still were well below the threshold value of 2.2 that indicates a high incidence of grass tetany. ${ }^{[8]}$

In 1994, crown ash varied among accessions, but no other elemental concentrations varied for crowns in 1994 or 1995. HiMag crowns contained less ash than parental cultivars in 1994, but not in 1995. Crown mass for all accessions was higher in 1994 than in 1995 (Table 3).

\section{Root Mass and Elemental Concentrations}

Root mass varied both among depths and between years, and the year by depth interaction was significant. The chemical analyses for roots 
Table 3. Means $(n=6)$ and root mean square errors (RMSE) for mass, ash, elemental concentrations, and cation $\mathrm{mol}_{c}$ ratios for crowns and root sections of tall fescue in a 7.6-cm diameter core in 0 - to $15-\mathrm{cm}(\mathrm{R} 1), 15-$ to $30-\mathrm{cm}(\mathrm{R} 2)$, and 30- to 45-cm (R3) depths. Concentrations are expressed on a tissue dry matter basis.

\begin{tabular}{|c|c|c|c|c|c|c|c|c|c|}
\hline & \multirow[b]{3}{*}{ Mass (g) } & \multicolumn{6}{|c|}{ Concentration } & \multicolumn{2}{|c|}{ Ratio $^{\text {a }}$} \\
\hline & & Ash & $\mathrm{K}$ & $\mathrm{Ca}$ & $\mathrm{Mg}$ & $\mathrm{Na}$ & $\mathrm{P}$ & $\mathrm{K}$ & $\mathrm{K}$ \\
\hline & & \multicolumn{6}{|c|}{$\left(\mathrm{g} \mathrm{kg}^{-1}\right)$} & $(\mathrm{Ca}+\mathrm{Mg})$ & $\mathrm{Mg}$ \\
\hline \multicolumn{10}{|c|}{1994 means } \\
\hline Crown & 9.36 & 103.0 & 9.03 & 5.96 & 1.94 & 1.15 & 1.42 & 0.51 & 1.46 \\
\hline R1 & 1.86 & 66.5 & 3.66 & 5.67 & 0.89 & 0.92 & 0.97 & 0.28 & 1.30 \\
\hline $\mathrm{R} 2$ & 0.40 & 71.4 & 2.73 & 6.13 & 0.81 & 1.23 & 0.95 & 0.20 & 1.06 \\
\hline R3 & 0.30 & 66.3 & 2.01 & 7.77 & 0.85 & 1.30 & 0.77 & 0.12 & 0.78 \\
\hline \multicolumn{10}{|c|}{1994 RMSE } \\
\hline Crown & 2.06 & 7.8 & 1.02 & 0.43 & 0.22 & 0.31 & 0.15 & 0.06 & 0.13 \\
\hline R1 & 0.27 & 7.7 & 1.09 & 1.92 & 0.21 & 0.25 & 0.17 & 0.07 & 0.27 \\
\hline $\mathrm{R} 2$ & 0.06 & 10.9 & 0.51 & 1.85 & 0.14 & 0.29 & 0.14 & 0.04 & 0.18 \\
\hline $\mathrm{R} 3$ & 0.10 & 12.3 & 0.46 & 2.49 & 0.21 & 0.30 & 0.14 & 0.03 & 0.14 \\
\hline \multicolumn{10}{|c|}{1995 means } \\
\hline Crown & 5.35 & 81.5 & 9.75 & 5.00 & 1.54 & 0.58 & 1.84 & 0.67 & 1.97 \\
\hline $\mathrm{R} 1$ & 2.13 & 76.3 & 5.98 & 5.27 & 1.04 & 0.76 & 1.13 & 0.46 & 1.84 \\
\hline $\mathrm{R} 2$ & 0.45 & 90.0 & 5.60 & 6.16 & 1.24 & 1.81 & 1.28 & 0.36 & 1.42 \\
\hline R3 & 0.29 & 83.0 & 3.15 & 9.23 & 1.45 & 1.94 & 1.00 & 0.16 & 0.73 \\
\hline \multicolumn{10}{|c|}{1995 RMSE } \\
\hline Crown & 1.43 & 14.6 & 2.23 & 1.07 & 0.19 & 0.12 & 0.27 & 0.18 & 0.39 \\
\hline R1 & 0.48 & 10.5 & 1.48 & 0.90 & 0.13 & 0.15 & 0.21 & 0.15 & 0.52 \\
\hline $\mathrm{R} 2$ & 0.32 & 17.5 & 1.10 & 1.31 & 0.18 & 0.40 & 0.25 & 0.08 & 0.26 \\
\hline R3 & 0.09 & 20.2 & 1.20 & 2.61 & 0.28 & 0.67 & 0.21 & 0.08 & 0.29 \\
\hline
\end{tabular}

${ }^{\mathrm{a}}$ Ratios are unit less but are calculated on $\mathrm{a} \mathrm{mol}_{c}$ basis.

conducted in 1994 were done with stained roots, whereas the 1995 roots were not stained. A methods evaluation using paired samples found that $76,65,55$, and $77 \%$ of the $\mathrm{K}, \mathrm{Ca}, \mathrm{Mg}$, and $\mathrm{Na}$ conc. in the roots, respectively, were present in stained compared to unstained roots (data not shown). Dry-ashing of the stained roots resulted in almost complete solubilization whereas digestion with nitric and perchloric acids was not complete. This suggests that the methylene blue stain may have chelated the cations that were adsorbed on the external root surface. The stain solution leached 2.04, 0.78, and $0.27 \mathrm{~g} \mathrm{~kg}^{-1}$ root of $\mathrm{K}, \mathrm{Ca}$, and $\mathrm{Mg}$, respectively, whereas the rinse solution contained no significant cation conc. 
Accessions did not vary in the R1 or R2 depth increments for elemental concentrations, cation ratios, or elemental uptake (analysis not shown) in either 1994 or 1995 . For the R3 root increment in 1994, the $\mathrm{K} / \mathrm{Mg}$ ratio for HiMag was 0.60 (contrast $P=0.01$ ) compared to 0.94 for KY31 and 0.81 for MO96. In 1995 accessions did not vary for any elemental characteristics in the $\mathrm{R} 3$ root increment.

\section{Root Length and Area}

Root length, area, and root length density in R1 (Table 4) were generally 2-3 times the values for R2 and R3. Length per kg root in R1 was less than R2 and R3. For R1 roots in 1994, HiMag had greater root length of large (>1 mm diameter) roots per unit weight $\left(9,290 \mathrm{~m} \mathrm{~kg}^{-1}\right)$ than KY31 $\left(7,710 \mathrm{~m} \mathrm{~kg}^{-1}\right)$ or MO96 $\left(7,260 \mathrm{~m} \mathrm{~kg}^{-1}\right)$, but accessions did not differ for this characteristic in 1995 . The small $(<1 \mathrm{~mm}$ diameter) roots for R1 were not statistically different among accessions in either year, and the R2 root characteristics did not differ between HiMag and its parents in 1994 or 1995 for either large or small roots. Accessions generally did not vary for root length or area for either large or small roots in the R3 depth increment in 1994 or 1995, except that HiMag had greater length of small roots per unit weight $\left(143,600 \mathrm{~m} \mathrm{~kg}^{-1}\right)$ than KY31 $\left(119,100 \mathrm{~m} \mathrm{~kg}^{-1}\right)$ or MO96 $\left(121,600 \mathrm{~m} \mathrm{~kg}^{-1}\right)$ in 1995.

\section{Relationships Between Chemical and Physical Characteristics}

Leaf $\mathrm{Mg}$ conc. was not significantly correlated to any physical measurement in HiMag, KY31, or MO96. However, leaf $\mathrm{Mg}$ and $\mathrm{Ca}$ were positively correlated in all three accessions (Table 5). Leaf $\mathrm{Mg}$ also was positively related to leaf K in KY31 and MO96 but not in HiMag. Leaf $\mathrm{K}$ conc. was negatively correlated with length of small roots and area for the R1 depth increment. This is probably because less soil $\mathrm{K}$ was taken up by fewer roots at the $\mathrm{R} 1$ depth increment, relative to the R2 or R3 depth increments where the soil $\mathrm{K}$ was lower (Table 1).

Root $\mathrm{Mg}$ conc. in the R1 depth increment was not highly correlated with R1 physical characteristics $(r<0.54)$ in the three accessions. Root $\mathrm{Mg}$ in $\mathrm{R} 1$ was strongly correlated with root $\mathrm{Ca}$ in $\mathrm{R} 1(P \leq 0.05, \mathrm{df}=23)$ for HiMag, KY31, and MO96. Root Mg conc. in the R2 depth increment was positively correlated to $\mathrm{R} 2$ small root lengths and root $\mathrm{K}$. Root $\mathrm{Mg}$ conc. was related to large root length with an $r$ value of 0.71 for HiMag. Root $\mathrm{Mg}$ was related to root $\mathrm{Ca}$ in $\mathrm{R} 3$ for all accessions. 


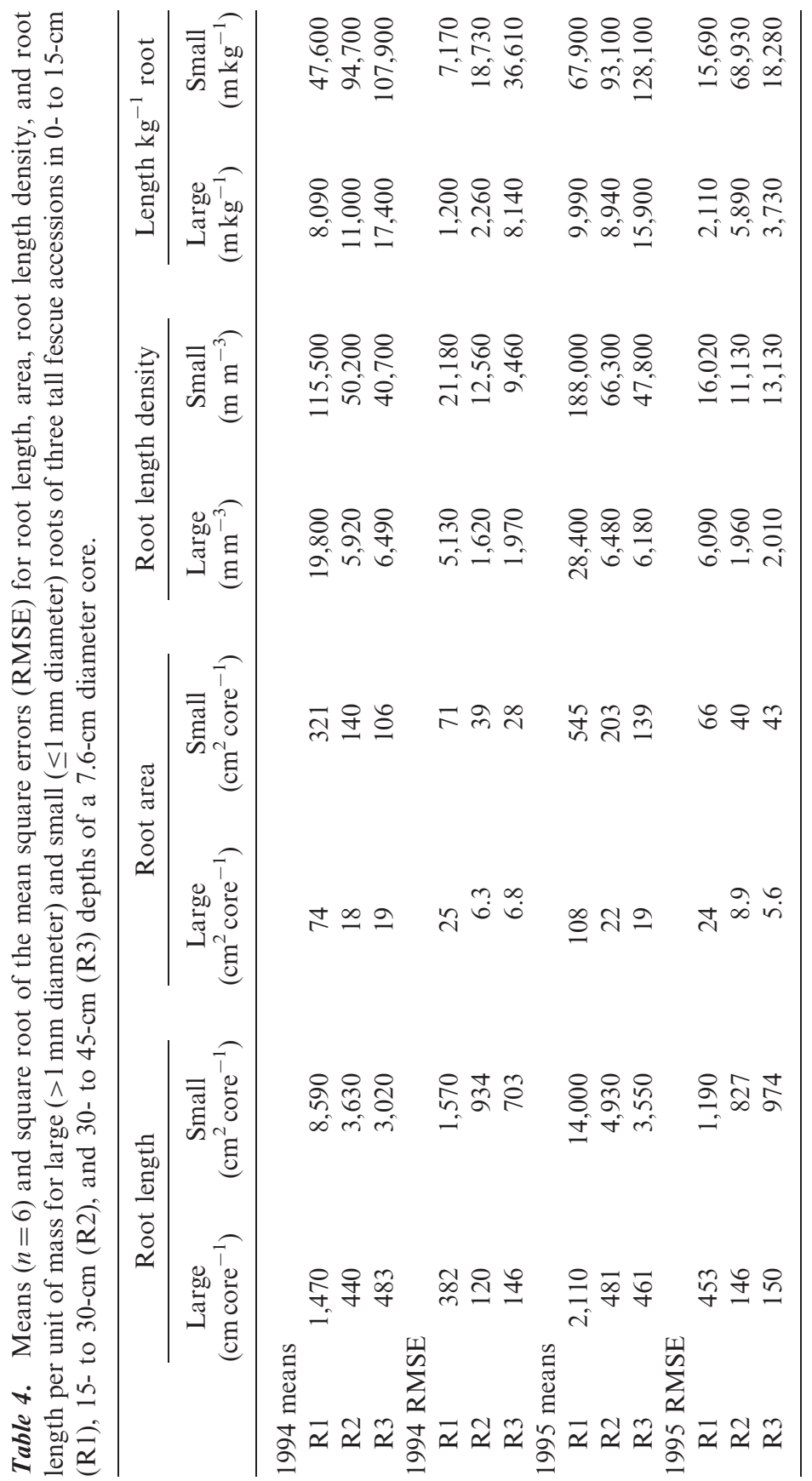


Table 5. Selected Pearson correlation coefficients $(r)$ between various chemical and physical characteristics of three tall fescue accessions. Values of $r$ are significant at $P=0.05(\mathrm{df}=23)$ if $r>0.40$.

\begin{tabular}{lccc}
\hline & \multicolumn{3}{c}{ Accession } \\
\cline { 2 - 4 } Relationship & HiMag & KY31 & MO96 \\
\hline Leaf Mg to Ca & $0.77^{* *}$ & $0.65^{* *}$ & $0.80^{* *}$ \\
Leaf Mg to K & 0.20 & $0.70^{* *}$ & $0.55^{* *}$ \\
Leaf K to R1 small root ${ }^{\text {a }}$ length & $-0.69^{* *}$ & $-0.42^{\text {d }}$ & $-0.48^{\text {d }}$ \\
Leaf K to R1 small root area & $-0.70^{* *}$ & -0.33 & $-0.45^{* *}$ \\
R1 Mg to R1 physical characteristics & $<0.40$ & $<0.30$ & $<0.54$ \\
R1 Mg to R1 Ca & $0.89^{* *}$ & $0.70^{* *}$ & $0.93^{* *}$ \\
R2 Mg to R2 small root length & $0.71^{* *}$ & 0.20 & $0.54^{* *}$ \\
R2 Mg to R2 K & $0.90^{* *}$ & $0.75^{* *}$ & $0.62^{* *}$ \\
R3 Mg to R3 large root ${ }^{\text {c }}$ length & $0.71^{* *}$ & $0.12^{* *}$ & $0.35^{* *}$ \\
R3 Mg to R3 Ca & $0.79^{* *}$ & $0.83^{* *}$ & $0.59^{* *}$ \\
\hline
\end{tabular}

${ }^{\text {a }}$ Small roots are defined as $<1 \mathrm{~mm}$ diameter.

${ }^{\mathrm{b}}$ Root length, area, and root length density; and root mass.

${ }^{\mathrm{c}}$ Large roots are defined as $>1 \mathrm{~mm}$ diameter.

${ }^{*},{ }^{* *}$, indicate significant $F$-test at $P<0.05$ and 0.01 , respectively.

The $\mathrm{Mg}^{2+}$ and $\mathrm{Ca}^{2+}$ ions are supplied to the roots by mass flow, whereas $\mathrm{PO}_{4}^{3-}$ and $\mathrm{K}^{+}$are supplied by diffusion. ${ }^{[19]}$ If it is assumed that $300 \mathrm{~kg}$ water was transpired $\mathrm{kg}^{-1}$ plant dry matter and whole plant $\mathrm{Mg}$ conc. of HiMag was $1.84 \mathrm{~g} \mathrm{~kg}^{-1}$, then $\mathrm{Mg}$ conc. needed in the soil solution $(X)$ can be calculated as ${ }^{[19]}$ :

$$
\begin{aligned}
X & =(1.84 \mathrm{mg} \mathrm{Mg} / \mathrm{g} \mathrm{DM}) \times(\mathrm{g} \mathrm{DM} / 300 \mathrm{~g} \text { water }) \times(1000 \mathrm{~g} / \mathrm{L}) \\
& =66.1 \mathrm{mg} \mathrm{Mg} \mathrm{L}^{-1}
\end{aligned}
$$

which is equivalent to $2.8 \mathrm{mmol} \mathrm{Mg}^{2+} \mathrm{L}^{-1}$. As a result, the average soil solution conc. of $1.8 \mathrm{mmol} \mathrm{L}^{-1}$ (Table 1) would provide less $\mathrm{Mg}$ by mass flow than required by the plant, suggesting some other process is involved, i.e., an active uptake mechanism for $\mathrm{Mg}$ in tall fescue.

\section{Citrate and Malate Concentrations in Roots}

No significant differences for R1 roots were observed for root tissue citrate concentrations of 0.66 (HiMag), 0.62 (KY31), and $0.47 \mathrm{mM}$ 
(MO96). There were no differences in malate concentrations of 1.51 (HiMag), 1.80 (KY31), and $1.39 \mathrm{mM}$ (MO96).

\section{DISCUSSION}

Leaf $\mathrm{Mg}$ concentration was higher in HiMag than parental cultivars, although this difference was not highly significant $(P=0.08)$ in 1994. Similarly, HiMag had higher concentrations of leaf $\mathrm{Mg}$ compared to KY31 and MO96 on an acidic Cecil soil ${ }^{[9]}$ and on the same soil as this study. ${ }^{[5]}$ Leaf $\mathrm{Mg}$ concentrations of HiMag, KY31, and MO96 were greater than $2 \mathrm{~g} \mathrm{~kg}^{-1}$, which is considered a low grass tetany risk. ${ }^{[9]}$

Roots in the three depth increments evaluated in our study did not consistently vary for $\mathrm{Mg}$ concentration, uptake, or $\mathrm{K} / \mathrm{Mg}$ and $\mathrm{K} /(\mathrm{Ca}+\mathrm{Mg})$ ratios for any of the three tall fescue accessions. Crowns had relatively small concentrations of $\mathrm{K}, \mathrm{Ca}$, and $\mathrm{Mg}$. In 1995, 80\% of $\mathrm{K}, 64 \%$ of $\mathrm{Ca}, 75 \%$ of $\mathrm{Mg}, 56 \%$ of $\mathrm{Na}$, and $77 \%$ of $\mathrm{P}$ were partitioned in aboveground portions of plants. Leaf Mg concentration for HiMag was about twice that in crowns and roots, whereas leaf Mg in KY31 and MO96 was about 1.5 times greater than the concentrations in crowns and roots. Sleper et al. ${ }^{[4]}$ reported that high $\mathrm{Mg}$ and $\mathrm{Ca}$ concentrations in leaves were highly heritable. Because leaf $\mathrm{Mg}$ concentration was greater in HiMag than MO96 or KY31 and root concentrations were generally not different, HiMag apparently absorbs and translocates more $\mathrm{Mg}$ from roots to leaves.

The question remains whether $\mathrm{Mg}$ is taken up actively. Both $\mathrm{Ca}$ and $\mathrm{Mg}$ concentrations in leaves were greater in HiMag than its parental cultivars, while $\mathrm{K}$ concentrations were about the same. Thus, one could hypothesize that HiMag has some characteristic that enhances transport of $\mathrm{Ca}$ and $\mathrm{Mg}$ from roots to leaves. Hannaway et al. ${ }^{[20]}$ reported $\mathrm{K}$ had a greater depressive effect on $\mathrm{Mg}$ translocation to the shoot than $\mathrm{Mg}$ uptake by roots in tall fescue.

Saturated paste extractable K in the $30-45 \mathrm{~cm}$ depth was about $30 \%$ of that in the $0-15 \mathrm{~cm}$ depth in Portneuf soil (Table 1). Magnesium uptake in plants depends on concentrations and activity of $\mathrm{Mg}$ in soil solution and ability of soil to replenish $\mathrm{Mg}$ in the soil solution. ${ }^{[19]}$ Availability of $\mathrm{Mg}$ is affected by the proportion of $\mathrm{Mg}$ relative to soluble and exchangeable amounts of $\mathrm{K}, \mathrm{Ca}, \mathrm{Na}$, aluminum $(\mathrm{Al})$, and manganese $(\mathrm{Mn}) .{ }^{[19]}$ Although root distributions were not different between accessions, if a plant was able to extract more soil solution from the $30-45 \mathrm{~cm}$ depth, this should be advantageous because the $\mathrm{K} / \mathrm{Mg}$ ratio would be lower because of $\mathrm{K}$ dilution, and more $\mathrm{Mg}$ would be available 
to the plant relative to $\mathrm{K}$. Although HiMag also contained more $\mathrm{Ca}$ and $\mathrm{Mg}$ in leaves from plants grown on acid soils, ${ }^{[9]}$ soluble cation concentrations in the soil were not reported.

Soil test $\mathrm{P}$ was adequate in our study and apparently was not related to leaf $\mathrm{Mg}$ concentration. Reinbott and Blevins ${ }^{[21]}$ reported that applying $\mathrm{P}$ fertilizers to KY31 growing in soil with low $\mathrm{P}$ increased $\mathrm{Ca}$ and $\mathrm{Mg}$ concentrations in leaf tissue. However, when soil test $\mathrm{P}$ levels were adequate, Wilkinson and Mayland ${ }^{[9]}$ found no evidence in support of the relationship of $\mathrm{P}$ fertilization to leaf $\mathrm{Mg}$ in tall fescue even when increased leaf $\mathrm{P}$ concentration resulted from $\mathrm{P}$ applications.

Root length, root surface area, and root length density did not vary consistently for accession in the three depth increments examined in our study (Table 4). Values for root length density in our study were generally similar to those $\left(45,000 \mathrm{~mm}^{-3}\right)$ for KY31 reported by Beyrouty et al. ${ }^{[22]}$ in Arkansas. Mycorrhizal associations through extension of their hyphae can increase effective root surface area. ${ }^{[19]}$ Hyphae may have affected $\mathrm{P}$ and $\mathrm{Mg}$ absorption in our study because mass flow did not supply enough $\mathrm{Mg}$ to the root surface to account for the amounts in shoots. Even if hyphae aided in the absorption of $\mathrm{Mg}$ into the root, mycorrhizal associations do not explain the transport of more $\mathrm{Mg}$ to the leaves of HiMag.

It was also hypothesized that HiMag might absorb more $\mathrm{Mg}^{2+}$ and $\mathrm{Ca}^{2+}$ because of enhanced organic acid production, which could balance the electrical charge. Charge balance theory suggests that electrical neutrality must be maintained. Thus, for every cation absorbed either an anion must be adsorbed or created organically in the root. Malate exchange, influx and efflux, occurred in root cells of carrot (Daucus carota L.) and barley (Hordeum vulgare L.). ${ }^{[23]}$ No evidence was found of enhanced citrate or malate in root tissues of the accessions, but organic acid exudates from roots into the soil were not measured.

Most of the root characteristics examined in our study did not vary among the three tall fescue accessions, and none of these characteristics were consistently related to elemental concentrations within the accessions. As a result, none of these characteristics appeared to explain the high leaf $\mathrm{Mg}$ concentrations for HiMag found in this study or other studies. $^{[5,9]}$ The process responsible for increased transport of $\mathrm{Mg}$ from roots to leaves of HiMag may be carrier-mediated transport because it can occur against an electrochemical or concentration gradient. Even though our study did not conclusively identify the factor(s) responsible for the high leaf $\mathrm{Mg}$ concentrations in HiMag, these results indicated that the root characteristics measured were not responsible for the higher concentrations in HiMag. 


\section{CONCLUSIONS}

HiMag exhibits higher leaf $\mathrm{Mg}$ concentrations than its parental cultivars; however, the mechanism for increased $\mathrm{Mg}$ concentrations is unknown. It was hypothesized that these high leaf $\mathrm{Mg}$ concentrations were due to differences in root characteristics, ability to absorb greater amounts of $\mathrm{Mg}$ into the roots, or a difference in the ability to transport the elements. However, none of the root characteristics examined in our study were consistently related to elemental concentrations in roots or leaves. Although HiMag had higher leaf concentrations of $\mathrm{Mg}$ than its parental cultivars, root and crown $\mathrm{Mg}$ concentrations did not differ among the three tall fescue accessions. This suggests that HiMag translocates more $\mathrm{Mg}$ from roots to leaves than its parents, and that HiMag has more active transport of $\mathrm{Mg}$. An experiment that measures energy flow in respiration would probably be necessary to address the active uptake hypothesis.

\section{ACKNOWLEDGMENTS}

The authors thank B. E. Mackey, USDA-ARS, Albany, CA for his assistance with statistical analyses; and D. A. Sleper, Univ. Missouri, Columbia, MO for endophyte-free seed.

\section{REFERENCES}

1. Mayland, H.F.; Grunes, D.L. Soil-climate-plant relationships on the etiology of grass tetany. In Grass Tetany; Rendig, V.V., Grunes, D.L., Eds.; ASA, CSSA, and SSSA: Madison, WI, 1979; ASA Spec. Publ. 35, 123-175.

2. Mayland, H.F. Factors affecting yield and nutritional quality of crested wheatgrass. In Crested Wheatgrass: Its Values, Problems and Myths, Symp. Proc., Johnson, K.L., Ed.; Utah State Univ.: Logan, UT, 1986; 215-266.

3. Buckner, R.C.; Powell, J.B.; Frakes, R.V. Historical development. In Tall Fescue; Buckner, R.C., Bush, L.B., Eds.; ASA, CSSA, and SSSA: Madison, WI, 1979; Agron. No. 20, 1-7.

4. Sleper, D.A.; Vogel, K.P.; Asay, K.H.; Mayland, H.F. Using plant breeding and genetics to overcome the incidence of grass tetany. J. Anim. Sci. 1989, 67, 3456-3462. 
5. Mayland, H.F.; Sleper, D.A. Developing a Tall Fescue for Reduced Grass Tetany Risk, Proc. 17th Int. Grassland Congress, Palmerston North, NZ, Feb. 13-16, 1993; Baker, M.J., Ed.; NZ Grassl. Assoc.: Palmerston North, 1993; 1095-1096.

6. Alderson, J.; Sharp, W.C. Grass Varieties in the United States; CRC Press: Boca Raton, FL, 1995; USDA Agric. Handbook No. 170.

7. Asay, K.H.; Frakes, R.V.; Buckner, R.C. Breeding and cultivars. In Tall Fescue; Buckner, R.C., Bush, L.P., Eds.; ASA, CSSA, and SSSA: Madison, WI, 1979; Agron. No. 20, 111-139.

8. Kemp, A.; t'Hart, M.L. Grass tetany in grazing milk cows. Neth. J. Agr. Sci. 1957, 5, 4-17.

9. Wilkinson, S.R.; Mayland, H.F. Yield and mineral concentration of HiMag compared to other tall fescue cultivars grown in the Southern Piedmont. J. Plant Nutr. 1997, 20, 1317-1331.

10. De la Fuente, J.M.; Ramierez-Rodriguez, V.; Cabrera-Ponce, J.L.; Herrerra-Estrella, L. Aluminum tolerance in transgenic plants by alteration of citrate synthesis. Science 1997, 276, 1566-1568.

11. Shewmaker, G.E.; Mayland, H.F.; Hansen, S.B. Cattle grazing preference among eight endophyte-free tall fescue cultivars. Agron. J. 1997, 89, 695-701.

12. Harris, G.A.; Campbell, G.S. Automated quantification of roots using a simple image analyzer. Agron. J. 1989, 81, 935-938.

13. Tennant, D. A test of a modified line intercept method of estimating root length. J. Ecol. 1975, 63, 995-1001.

14. Perkin-Elmer Corp. Agriculture. Analytical Methods for Atomic Absorption Spectrophotometry; Perkin-Elmer Corp.: Norwalk, CT, 1982; AY-1-7.

15. Kitson, R.E.; Mellon, M.G. Colorimetric determination of phosphorus as molydivanado phosphoric acid. Ind. Eng. Chem. Anal. Ed. 1944, 16, 379.

16. Callaway, T.R.; Martin, S.A.; Wampler, J.L.; Hill, N.S.; Hill, G.M. Malate content of forage varieties commonly fed to cattle. J. Dairy Sci. 1997, 80, 1651-1655.

17. Robbins, C.W.; Wiegand, C.L. Field and laboratory measurements. In Agricultural Salinity Assessment and Management; Tanji, K.K., Ed.; ASCE: New York, 1990; ASCE Manual No. 71, 203-219.

18. Steel, R.G.D.; Torrie, J.H. Principles and Procedures of Statistics; McGraw-Hill: New York, 1960.

19. Barber, S.A. Nutrient absorption by plant roots. In Soil Nutrient Bioavailability: A Mechanistic Approach; Barber, S.A., Ed.; J. Wiley \& Sons: New York, 1984; 55-89. 
20. Hannaway, D.B.; Bush, L.P.; Leggett, J.E. Mineral composition of Kenhy tall fescue as affected by nutrient solution concentrations of Mg and K. J. Plant Nutr. 1982, 5, 137-151.

21. Reinbott, T.M.; Blevins, D.G. Phosphorus and temperature effects on magnesium, calcium, and potassium in wheat and tall fescue leaves. Agron. J. 1994, 86, 523-529.

22. Beyrouty, C.A.; West, C.P.; Gbur, E.E. Root development of bermudagrass and tall fescue as affected by cutting interval and growth regulators. Plant Soil 1990, 127, 23-30.

23. Cram, W.J.; Laties, G.G. The kinetics of bicarbonate and malate exchange in carrot and barley root cells. J. Exp. Bot. 1974, 25, 11-27. 